\title{
Development of seed production elements of new grain beans variety Yuzhanka bred by FSBSI Federal Scientific Rice Centre
}

\author{
Grigory Pischulin and Lybov Esaulova* \\ Federal Scientific Rice Centre, 350921, Krasnodar, Belozerny, 3, Russia
}

\begin{abstract}
For the rapid distribution and successful cultivation of beans, it is necessary to develop methods of cultivation technology in accordance with the soil and climatic conditions of Krasnodar region. In this regard, the aim of this work was to study the efficiency of irrigation, various doses of mineral nutrition and the use of the biological product Nitragin KM on grain beans crops. The effect of pre-sowing application of mineral fertilizers under irrigation and rainfed conditions on phenological, morphological traits, yield and productivity of grain beans variety Yuzhanka has been studied. Analysis of the data on the yield of beans seeds showed that the most effective agricultural method for seed production of this crop is the introduction of mineral fertilizers on drip irrigation. With an increase in the level of mineral nutrition, the seed multiplication factor increased from 30 to $45 \mathrm{pcs} / \mathrm{pcs}$ on dry land and from 50 to $69 \mathrm{pcs} / \mathrm{pcs}$ during irrigation. The application of mineral fertilizers contributed to an increase in yields both in rainfed and irrigated conditions. The highest yield of bean seeds of variety Yuzhanka was obtained with the use of fertilizers at a dose of $\mathrm{N}_{30} \mathrm{P}_{30} \mathrm{~K}_{30}(1,77 \mathrm{t} / \mathrm{ha}$ on dry land and 3,04 t/ha on irrigated plots).
\end{abstract}

\section{Introduction}

A necessary direction in the development of plant growing is considered to be the growth and production of vegetable protein through the cultivation of legumes. Modern agricultural production has a fairly wide variety of types of legumes, among which beans stand out for their nutritious and varied uses. [1].

Beans (Phaseolus vulgaris L.) contain nutritious and functional compounds and constitute the main diet for about one third of the world's population [2]. Kidney beans are an important food staple produced mainly in drought-prone regions. Therefore, it is important to grow varieties adapted to limited irrigation and grain of which contains high levels of health-related phytochemicals without compromising seed yield. [3]. Ripe beans contain $17-33 \%$ protein, $0.8-3.6 \%$ fat, $50-60 \%$ starch, $5-8 \%$ fiber.

In terms of acreage, beans ranks second in the world among leguminous crops after soybeans. In Russia, its area is not significant [4]. According to many researchers, beans grow well and give a high yield on slightly acidic and close to neutral soils [5]. The

\footnotetext{
${ }^{*}$ Corresponding author: 1.esaulova@mail.ru
} 
optimum pH is between 6 and 7. On highly acidic soils, beans do not yield high yields. Young shoots are especially sensitive to acidic soil reactions. On such soils, the development of tuberous bacteria slows down, and the effect of the introduction of nitragin weakens.

Beans, like other legumes, are in symbiosis with tuberous bacteria of a special group of bacteria [6]. These bacteria form colonies and are visible to the naked eye on the roots of

the bean. Tuberous bacteria fix nitrogen from the air and provide legumes with additional nutrition in the form of nitrogen compounds.

Problems with nitrogen nutrition in legumes are the most difficult. The available data on them in the literature are very contradictory. Some researchers, such as K.V. Neverov, L.V. Kukresh [7,8] believe that legumes in symbiosis with nodule bacteria are capable of supplying nitrogen, so the use of nitrogen fertilizers under them is impractical. The opposite opinion was expressed by other researchers, who believe that it is possible to achieve the highest possible productivity of leguminous crops when used as symbiotic bound nitrogen and nitrogen fertilizers. In addition, proponents of a mixed type of nitrogen nutrition have inconsistencies in the issue of doses of mineral nitrogen. Some researchers believe that this should be about $45-60 \mathrm{~kg} / \mathrm{ha}$ on average doses of nitrogen fertilizers [9], others [10] favor small (initial) doses of nitrogen.

The growth and development of beans are accompanied by different requirements for soil moisture. Beans (Phaseolus vulgaris L.) are an important cultivated plant worldwide with a high water consumption at the initial stage of development [11]. If before budding the beans can withstand a short-term drought, then during the flowering and ripening of beans, a sufficient amount of moisture is required both in the soil and in the air [12]. Excessive moisture during the full maturity of seeds slows down their ripening and reduces their quality, often even leading to the death of plants. However, different varieties have different moisture requirements [13].

Thus, beans make high demands on growing conditions, which is a limiting factor in their introduction into the production of Krasnodar region and new growing regions.

In this regard, the development of elements of the production technology for a new promising variety Yuzhanka bred by FSBSI Federal Scientific Rice Centre depending on the doses of mineral fertilizers, irrigation and biological products, is urgent.

The aim of the research is to determine the effectiveness of the influence of drip irrigation on the seed productivity of beans, to study the effect of doses of mineral fertilizers and the bacterial preparation Nitragin KM on the features of the production process of beans.

\section{Materials and methods}

Breeding and seed-production work was carried out in accordance with the "Methodological guidelines for breeding and primary seed production of legumes" (1980), records and observations with the "Methodology of experiments in vegetable growing" [1], statistical processing of experimental results - according to B. A. Dospekhov and V.A/ Dzyuba [14], analysis of meteorological indicators according to the data of the agrometeorological post in Belozerny, Krasnodar. The area of the accounting plot is $10 \mathrm{~m}^{2}$, the replication is threefold. Allocation of plots is systematic with sequential placement of variants. Fertilizers were applied locally, in furrows made for sowing. Fertilization rate according to the test scheme. Sowing was carried out manually, according to the belt scheme $(90+50) / 2 \times 9-10 \mathrm{~cm}$. The seeding rate of seeds is $110-130 \mathrm{~kg} / \mathrm{ha}(130-150$ g/plot). Bean seeds were sown on April 29, seedlings were obtained in 8 - 9 days - May 7 8. Drip irrigation, according to the experiment scheme, was switched on May 14. 
In the course of phenological observations, the dates of the onset of the following phases were noted: germination, flowering, ripening (biological ripeness). The morphological description was carried out according to the following traits: the height of the bush and the attachment of the lower bean relative to the soil surface; color of leaves, flowers; the number of beans on the bush, their shape, size, color; shape, size, color of seeds; their number in the bean. On plots of grain beans, the planting density, their productivity was taken into account, the yield and weight of 1000 seeds were determined. At the same time, samples were taken to determine the content of dry matter, sugar, starch, ascorbic acid, protein and fiber in the grain. Visual assession for resistance to the main disease of beans - bacteriosis was performed.

\section{Results}

Recently, interest in beans in Russia has been constantly growing due to the beginning of the construction process of new processing enterprises, which require both green pod and beans as raw materials. To meet the increasing demand for raw materials, industrial production of beans is necessary, however, at present this crop is mainly cultivated in personal subsidiary farms, while the yield of green pod for vegetable beans is $7,0-8,0 \mathrm{t} / \mathrm{ha}$, many varieties in technical ripeness have fiber and parchment layer, grain (shelling) beans have a grain yield of $0,9-1,2 \mathrm{t} / \mathrm{ha}$ and it is often unsuitable for processing. One of the main reasons for this state with the cultivation of this crop is the lack of varieties suitable for use in the region and the lack of technology for their cultivation. In this regard, we conducted research on the development of technology elements for the cultivation of a new beans variety Yuzhanka, depending on the doses of mineral fertilizers, irrigation and biological products in the South of Russia.

It should be noted that in 2020 the end of April was favorable for the germination of bean seeds, the air temperature was $+11,2 \mathrm{C}$, due to the precipitation there was enough moisture, which led to the simultaneous emergence of seedlings.

The carried out accounting of the plant density showed that this indicator varied significantly depending on the application rate of mineral fertilizers. With an increase in the rate of fertilization, the crop density decreased. The greatest sparseness was observed in the variant with the introduction of $\mathrm{N}_{60} \mathrm{P}_{60} \mathrm{~K}_{60}$, only 117,3 pcs/ha.

The reason for this, in all likelihood, is the effect of the high concentration of salts of mineral fertilizers applied during sowing into the furrows, directly into the seed germination zone.

Phenological observations have shown differences in the timing of the stages of plant development in the studied sample of haricot beans (Table 3). So the interphase periods of the variety Yuzhanka were 31 - 36 days from germination to flowering, the biological ripeness of the beans in the variant without irrigation came on the 65th day after the mass emergence of seedlings. The use of drip irrigation additionally lengthened the growing season for variety Yuzhanka by 6 days. According to the duration of the growing season, the variety belongs to mid-ripening period.

The studied agricultural practices had different effects on the bean plants of the variety Yuzhanka (Table 1). Fertilization contributed to an increase in plant height by $4-7 \mathrm{~cm}$ on dry land and by $8-14 \mathrm{~cm}$ during irrigation. At the same time, in the variants without irrigation, this indicator averaged $42 \mathrm{~cm}$, and on irrigation it was already $54 \mathrm{~cm}$. Application of mineral fats caused a significant increase in the number of beans on the plant. At the same time, an increase in the mass of 1000 seeds was observed in nonirrigated conditions in the variant with the introduction of $\mathrm{N}_{30} \mathrm{P}_{30} \mathrm{~K}_{30}$ by $29-44 \mathrm{~g}$, with irrigation by 20-35 g. However, due to a decrease in the number of seeds in a bean in plants from plots where fertilizers were applied, their productivity did not increase and was 
at the level with the control, except for the $\mathrm{N}_{60} \mathrm{P}_{60} \mathrm{~K}_{60}$ variant on irrigation, where the increase is $5,9 \mathrm{~g}$ higher than in the control variant and statistically reliable. The use of the Nitragin KM preparation contributed to an increase in the number of beans per plant in the variants on dry land and the number of grains in a bean in the variants with the introduction of N60P60K60 on irrigation. But this did not allow increasing the productivity of plants, which was in all variants with this preparation at a level with the variants where it was not used.

Table 1. Plant productivity elements of beans variety Yuzhanka

\begin{tabular}{|c|c|c|c|c|c|c|c|}
\hline \multirow[t]{2}{*}{ Variant } & \multirow{2}{*}{$\begin{array}{c}\text { Height, } \\
\mathrm{cm}\end{array}$} & \multirow{2}{*}{$\begin{array}{l}\text { Height of } \\
\text { the } \\
\text { attachment } \\
\text { of the lower } \\
\text { bean }\end{array}$} & \multicolumn{3}{|c|}{ Per one plant } & \multirow{2}{*}{$\begin{array}{l}\text { Mass of } \\
1000 \\
\text { seeds, } g\end{array}$} & \multirow{2}{*}{$\begin{array}{c}\text { Yield, } \\
\text { t/ha }\end{array}$} \\
\hline & & & $\begin{array}{c}\text { Number } \\
\text { of beans, } \\
\text { pcs }\end{array}$ & $\begin{array}{l}\text { Mass of } \\
\text { beans, } g\end{array}$ & $\begin{array}{l}\text { Mass of } \\
\text { seeds, } g\end{array}$ & & \\
\hline $\begin{array}{l}\text { Dry land } \\
\mathrm{N}_{0} \mathrm{P}_{0} \mathrm{~K}_{0}\end{array}$ & 38 & 18 & 10 & 14,2 & 10,4 & 346 & 1,64 \\
\hline $\begin{array}{c}\text { Dry land } \\
\mathrm{N}_{30} \mathrm{P}_{30} \mathrm{~K}_{30}\end{array}$ & 45 & 17 & 12 & 14,8 & 11,7 & 390 & 1,77 \\
\hline $\begin{array}{l}\text { Dry land } \\
\mathrm{N}_{60} \mathrm{P}_{60} \mathrm{~K}_{60}\end{array}$ & 42 & 18 & 13 & 13,8 & 10,9 & 324 & 1,29 \\
\hline LSD $_{05}$ & 4 & 2 & 2 & 2,1 & $\mathbf{0 , 9}$ & 25 & $\mathbf{0 , 1 5}$ \\
\hline $\begin{array}{c}\text { Dry land } \\
\text { Nitragrin KM } \\
\mathrm{N}_{0} \mathrm{P}_{0} \mathrm{~K}_{0} \\
\end{array}$ & 43 & 16 & 11 & 12,0 & 8,3 & 276 & 1,31 \\
\hline $\begin{array}{c}\text { Dry land } \\
\text { Nitragrin KM } \\
\mathrm{N}_{30} \mathrm{P}_{30} \mathrm{~K}_{30}\end{array}$ & 45 & 17 & 15 & 17,3 & 11,2 & 305 & 1,70 \\
\hline $\begin{array}{c}\text { Dry land } \\
\text { Nitragrin KM } \\
\mathrm{N}_{60} \mathrm{P}_{60} \mathrm{~K}_{60}\end{array}$ & 46 & 15 & 18 & 22,3 & 13,2 & 293 & 1,57 \\
\hline $\mathbf{L S D}_{05}$ & 4 & 2 & 2 & 2,6 & $\mathbf{0 , 9}$ & 29 & $\mathbf{0 , 1 5}$ \\
\hline $\begin{array}{c}\text { Irrigation } \\
\text { NPK0 }\end{array}$ & 47 & 18 & 19 & 35,0 & 17,2 & 365 & 2,71 \\
\hline $\begin{array}{c}\text { Irrigation } \\
\text { NPK30 }\end{array}$ & 55 & 17 & 30 & 53,0 & 20,0 & 400 & 3,04 \\
\hline $\begin{array}{c}\text { Irrigation } \\
\mathrm{N}_{60} \mathrm{P}_{60} \mathrm{~K}_{60}\end{array}$ & 61 & 18 & 29 & 43,6 & 23,1 & 391 & 2,74 \\
\hline LSD $_{05}$ & 5 & 2 & 3 & 4 & 2,4 & 38 & $\mathbf{0 , 2 8}$ \\
\hline $\begin{array}{c}\text { Irrigation } \\
\text { Nitragrin KM } \\
\text { NPK0 }\end{array}$ & 52 & 14 & 19 & 27,6 & 18,6 & 372 & 2,93 \\
\hline $\begin{array}{c}\text { Irrigation } \\
\text { Nitragrin KM } \\
\text { NPK30 }\end{array}$ & 57 & 15 & 21 & 29,0 & 21,3 & 392 & 3,23 \\
\hline $\begin{array}{c}\text { Irrigation } \\
\text { Nitragrin KM } \\
\mathrm{N}_{60} \mathrm{P}_{60} \mathrm{~K}_{60}\end{array}$ & 55 & 16 & 22 & 37,6 & 24,2 & 350 & 2,87 \\
\hline LSD $_{05}$ & 5 & 1 & 2 & 3,6 & 2,3 & 37 & $\mathbf{0 , 3 0}$ \\
\hline
\end{tabular}

\section{Discussion}

In the course of the research, the multiplication coefficient of haricot bean seeds was revealed (Table 2). With an increase in the level of mineral nutrition, this ratio increased from 30 to $45 \mathrm{pcs} / \mathrm{pcs}$ on dry land and from 50 to $69 \mathrm{pcs} / \mathrm{pcs}$ during irrigation. The highest 
value of the multiplication factor of seeds was noted in the variant with the application of mineral fertilizers in a dose of $\mathrm{N}_{60} \mathrm{P}_{60} \mathrm{~K}_{60}$, both on dry land 45 pcs/pcs, and with irrigation $69 \mathrm{pcs} / \mathrm{pcs}$.

Table 2. Multiplication coefficient of haricot beans depending on irrigation and level of mineral nutrition

\begin{tabular}{|l|c|c|c|}
\hline \multirow{2}{*}{$\begin{array}{c}\text { Level of mineral } \\
\text { nutrition }\end{array}$} & \multicolumn{2}{|c|}{ Yuzhanka } & \multirow{2}{*}{ Mean value } \\
\cline { 2 - 3 } & Dry land & Irrigation & \\
\hline $\mathrm{N}_{0} \mathrm{P}_{0} \mathrm{~K}_{0}$ & 30 & 50 & 40 \\
\hline $\mathrm{N}_{30} \mathrm{P}_{30} \mathrm{~K}_{30}$ & 36 & 51 & 43 \\
\hline $\mathrm{N}_{60} \mathrm{P}_{60} \mathrm{~K}_{60}$ & 45 & 69 & 57 \\
\hline Mean value & 37 & 57 & \\
\hline Irrigation (factor $\mathrm{A}) \mathrm{F}_{\mathrm{f}} 4324,55>\mathrm{F}_{\mathrm{t}} 4,74$ & LSD 0,49 \\
\hline \multicolumn{2}{|l|}{ Mineral nutrition $($ factor $\mathrm{B}) \mathrm{F}_{\mathrm{f}} 1204>\mathrm{F}_{\mathrm{t}} 3,88$} & LSD 0,54 \\
\hline \multicolumn{2}{|l}{ Interaction (factor $\mathrm{AB}) \mathrm{F}_{\mathrm{f}} 57,76>\mathrm{F}_{\mathrm{t}} 3,88$} & LSD 0,93 \\
\hline
\end{tabular}

Analysis of variance of the obtained data revealed the proportions of influence factor of various rates of mineral nutrition and the use of drip irrigation, as well as their interaction on multiplication coefficient. The study of the interaction between the multiplication coefficient of beans and the studied factors made it possible to establish the specifics of the contribution of mineral nutrition and drip irrigation. According to the data obtained, the differences in the seed multiplication coefficient are significant $\left(F_{f}>F_{t}\right)($ Table 3). However, the variability of the number of seeds in the yield per unit area to a greater extent (Fig. 1) $63,02 \%$ is exerted by the use of drip irrigation, the effect of mineral nutrition on the multiplication coefficient is to a lesser extent $-35.11 \%$. The effect of interaction of the studied factors on the multiplication coefficient of haricot beans is very small and amounts to $1,68 \%$, the error is $0,17 \%$.

Table 3. Results of two-way analysis of variance for the multiplication coefficient of beans grain

\begin{tabular}{|c|c|c|c|c|c|}
\hline \multirow{2}{*}{ Types of variation } & \multirow{2}{*}{$\begin{array}{c}\text { Number of } \\
\text { degrees of } \\
\text { freedom }\end{array}$} & \multirow{2}{*}{$\begin{array}{c}\text { Quadratic } \\
\text { sum }\end{array}$} & \multirow{2}{*}{ Dispersion } & \multicolumn{2}{|l|}{ Fisher's criterion (F) } \\
\cline { 5 - 6 } & 1 & 1754,68 & 1754,68 & 4324,55 & actual \\
\hline Irrigation (factor A) & 2 & 977,72 & 488,86 & 1204,84 & 3,88 \\
\hline Mineral fertilizers (factor B) & 2 & 46,87 & 23,43 & 57,76 & 3,88 \\
\hline Interaction & 12 & 4,86 & 0,40 & & \\
\hline Acceptable error & 17 & 2784,16 & & & \\
\hline Total & 17 &
\end{tabular}

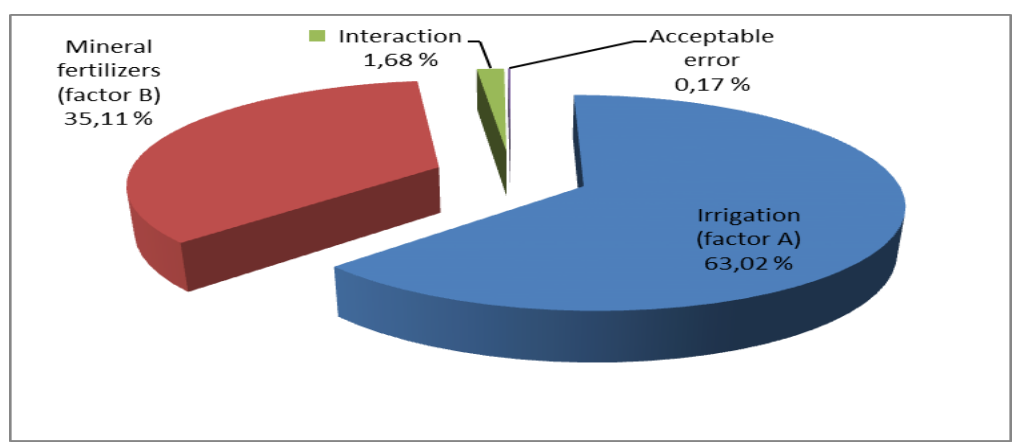

Fig. 1. Multiplication coefficient of grain beans. 
On the crops of the variety Yuzhanka of the studied agricultural practices, the greatest effect was obtained from the use of drip irrigation and application of mineral fertilizers. With irrigation, the yield of seeds averaged for all variants - 2,83-3,01 t/ha, which is 80,3 $96,8 \%$ higher than on dry land.

The application of mineral fertilizers contributed to an increase in yields both in rainfed and irrigated conditions. The highest yield of bean seeds of variety Yuzhanka was obtained with the use of fertilizers at a dose of $\mathrm{N}_{30} \mathrm{P}_{30} \mathrm{~K}_{30}(1,77 \mathrm{t} / \mathrm{ha}$ on dry land and 3,04 t/ha on irrigated plots) (Table 4).

Table 4. Impact of different agricultural measures on seed yield of haricot beans, $t / \mathrm{ha}$

\begin{tabular}{|l|c|c|c|c|}
\hline \multirow{2}{*}{$\begin{array}{l}\text { Level of } \\
\text { mineral } \\
\text { nutrition }\end{array}$} & \multicolumn{4}{|c|}{ Yuzhanka } \\
\cline { 2 - 5 } & $\begin{array}{c}\text { dry } \\
\text { land }\end{array}$ & $\begin{array}{c}\text { dry land } \\
\text { nitragrin } \\
\text { km }\end{array}$ & irrigation & $\begin{array}{c}\text { irrigation } \\
\text { nitragrin } \\
\text { km }\end{array}$ \\
\hline $\mathrm{N}_{0} \mathrm{P}_{0} \mathrm{~K}_{0}$ & 1,64 & 1,31 & 2,71 & 2,93 \\
\hline $\mathrm{N}_{30} \mathrm{P}_{30} \mathrm{~K}_{30}$ & 1,77 & 1,70 & 3,04 & 3,23 \\
\hline $\mathrm{N}_{60} \mathrm{P}_{60} \mathrm{~K}_{60}$ & 1,29 & 1,57 & 2,74 & 2,87 \\
\hline Mean value & 1,57 & 1,53 & 2,83 & 3,01 \\
\hline
\end{tabular}

The use of Nitragin KM on the crops of variety Yuzhanka grown in rainfed conditions was ineffective (Fig. 2). Under irrigation conditions, this agricultural practice allowed to increase the seed yield by an average of $6,5 \%$ in comparison with the variants where this preparation was not used.

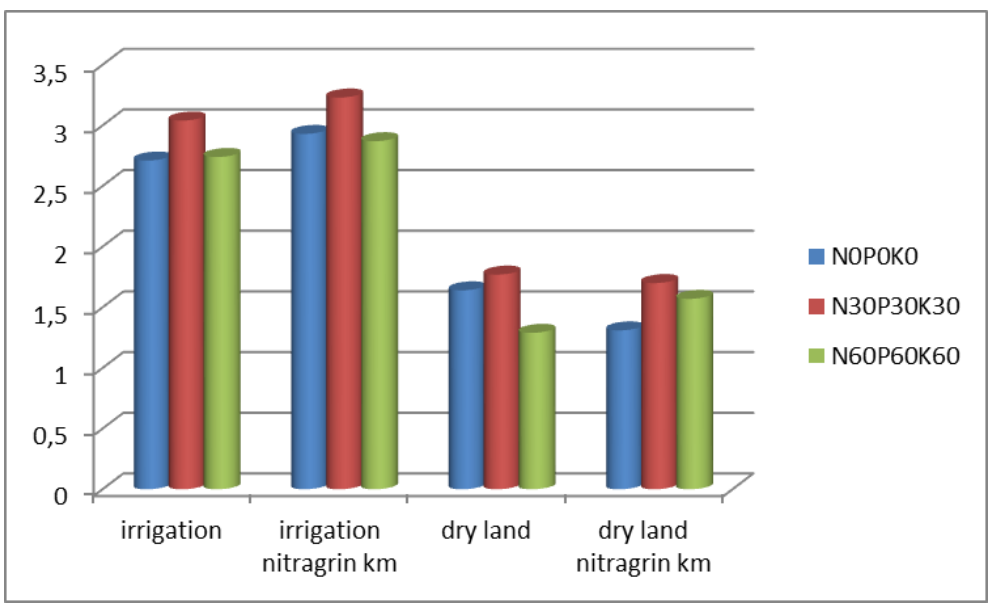

Fig. 2. Impact of biopreparation on variety Yuzhanka

The correlation relationship between the rates of applied fertilizers, Nitragin KM, the use of irrigation, and biochemical indicators of the beans grain quality has not been established. The dry matter content in grain was within $88,0-89,1 \%$, starch $24,4-36,6 \%$, protein $13,1-20,0 \%$.

\section{Conclusion}

The studied agricultural practices (drip irrigation, the use of mineral fertilizers and the bacterial preparation Nitragin KM) had a significant effect on the growth of beans and their productivity. The application of mineral fertilizers contributed to the increase in the number 
of beans on the plant. At the same time, an increase in the mass of 1000 seeds was observed in non-irrigated conditions in the variant with the introduction of $\mathrm{N}_{30} \mathrm{P}_{30} \mathrm{~K}_{30}$ for $29-44 \mathrm{~g}$, with irrigation for 20-35 g.

With an increase in the level of mineral nutrition, the seed multiplication coefficient increased from 30 to $45 \mathrm{pcs} / \mathrm{pcs}$ on dry land and from 50 to $69 \mathrm{pcs} / \mathrm{pcs}$ during irrigation. The highest yield of bean seeds of variety Yuzhanka was obtained with the application of fertilizers at a dose of $\mathrm{N}_{30} \mathrm{P}_{30} \mathrm{~K}_{30}-1,77 \mathrm{t} / \mathrm{ha}$ on dry land and 3,04 t/ha on irrigated plots. The use of the bacterial preparation Nitragin KM on beans in non-irrigated conditions is ineffective. Under irrigation conditions, this agricultural practice allowed to increase the seed yield of variety Yuzhanka by 6,5\% in comparison with the variants where this preparation was not used. The high concentration of salts of mineral fertilizers applied during sowing into the furrows, directly into the seed germination zone, reduces the plant density. The greatest sparseness of crops of 117,3 thousand plants/ha was noted in the variants where fertilizers were applied at a dose of $\mathrm{N}_{60} \mathrm{P}_{60} \mathrm{~K}_{60}$.

\section{References}

1. Mitrofanov, A.S. One-year legumes / A.S. Mitrofanov // Reserves for increasing the production of vegetable protein. - M.: - 1972. p. 119-178.

2. Bianca Pio Ávila et al. Proteomic and physicochemical characteristics: The search for a quality profile of beans (Phaseolus vulgaris L.) during long-term storage. LWT. Volume 133, November 2020, 110057. https://doi.org/10.1016/j.lwt.2020.110057

3. Mayra Denise Herrera et al. Impact of soil moisture on common bean (Phaseolus vulgaris L.) phytochemicals. Journal of Food Composition and Analysis. Volume 99, June 2021, 103883. https://doi.org/10.1016/j.jfca.2021.103883

4. Plant growing /under editorship of G.S. Podsypanov. M.: Kolos, 2006. - 612 p.

5. Ivanov, L.I. Climatic theory of the formation of organic substances / L.I. Ivanov. - M.: Publishing house of the ANSSSR, 1961.- 120

6. Shumny, V.K. Biological nitrogen fixation / V.K. Shumny et al. M., 1991. - 361 p.

7. Neverov, K.V. Using the mechanisms of action of stimulants, chlorophyll biosynthesis on the photostability of the photosynthetic apparatus / K.V. Neverov. - M., 1994. 24 p.

8. Kukresh, L.V. Legumes / L.V. Kukresh, N.P. Lukashevich. Minsk. 1992. 205 p.

9. Golubeva, G.S. Ways to increase the production of leguminous crops / G.S. Golubeva. - M., 1988. 40 p.

10. Kucey, R.M.N. The influence of rate and time mineral $\mathrm{N}$ application on yield and $\mathrm{N} 2$ fixation by field bean / R.M.N. Kucey // Nicaragua. 1989, 63p.

11. Rodolfo Schmit et al. Salicylic acid application in the initial development of beans (Phaseolus vulgaris L.) under water stress conditions: Agronomical and antioxidant parameters. Biocatalysis and Agricultural Biotechnology. Volume 31, January 2021, 101896. https://doi.org/10.1016/j.bcab.2020.101896

12. Method of sowing beans: Pat. 2192110 Rus. Federation: MPK7: A01C 7/00, A01B 79 / 00. / Letunovsky V.I., Akulov A.S.; applicant and patentee All-Russian Research Institute of Legumes and Groats. - No. 2000131785/13; declared 18.12.00; publ. 10.11.02.

13. Leguminous crops: textbook. Manual for universities / D. Shpaar et al. - Minsk: FUAinform, 1980.-221 p.

14. Dzyuba V.A. Multivariate experiments and methods of biometric analysis of experimental data. Guidelines. Krasnodar, 2007. - 76 p. 